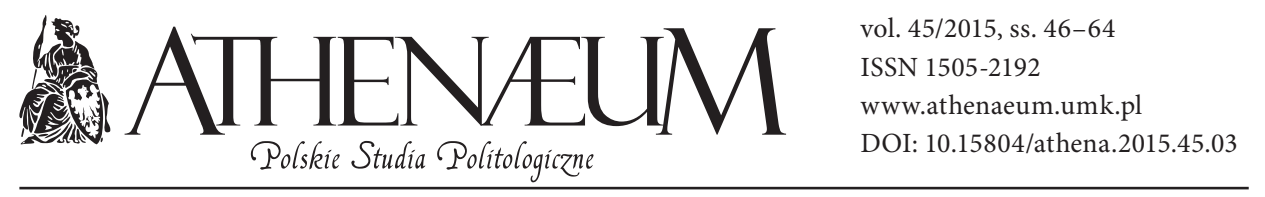

\title{
PROJEKTY REFORM AMERYKAŃSKIEGO SYSTEMU WYBORCZEGO NA SZCZEBLU FEDERALNYM, STANOWYM I LOKALNYM*
}

\author{
Anna Dziduszko-Rościszewska** \\ PROJECTS OF REFORMS OF THE AMERICAN ELECTORAL \\ SYSTEM AT THE FEDERAL, STATE AND LOCAL LEVEL
}

\begin{abstract}
The decentralized structure of the U.S. electoral system makes it impossible to speak about a single electoral system which operates in the United States covering about 16.000 elections that are held over a four-year period. States, responsible for holding elections at the state and local level, are trying to reform this system. A significant role in promoting and implementing these reforms is played by non-governmental organizations such as FairVote: The Center for Voting and Democracy, The League of Women Voters, and Common Cause. The purpose of this article is to present the proposed reforms of the U.S. electoral system at the federal, state and local level. The aim is to show the debate which takes place on the American political scene, on the issue of organizing more representative elections.
\end{abstract}

\section{KEYWORDS -}

elections to the House of Representatives, presidential elections, the U.S. electoral system, electoral reform, primaries

* Artykuł został sfinansowany ze środków Narodowego Centrum Nauki (nr grantu N N116 781840, konkurs 40, NCN).

** Uniwersytet Jagielloński w Krakowie, Instytut Nauk Politycznych i Studiów Międzynarodowych. 
Amerykański system wyborczy cechuje się wysokim poziomem zdecentralizowania, co sprawia, iż nie można mówić o jednym (powszechnym) systemie wyborczym, który obowiązuje w Stanach Zjednoczonych, ale o około 16 tysięcy wyborach, które odbywają się co cztery lata1. Stany, pod których jurysdykcję podlega organizacja wyborów na szczeblu stanowym i lokalnym, dążą do zreformowania owego systemu celem stworzenia bardziej reprezentatywnych wyborów. Znaczącą rolę w promowaniu i wdrażaniu owych reform odgrywają organizacje pozarządowe, takie jak Center for Voting and Democracy - FairVote, League of Women Voters czy Common Cause.

Celem niniejszego artykułu jest zaprezentowanie projektów reform amerykańskiego systemu wyborczego na szczeblu federalnym, stanowym i lokalnym i ukazanie debaty, jaka toczy się na amerykańskiej scenie politycznej w kwestii wprowadzenia wyborów o bardziej reprezentatywnym charakterze.

\section{WYBORY DO IZBY REPREZENTANTÓW I DO SENATU}

Wybory do Izby Reprezentantów i do Senatu odbywają się w wyborach powszechnych, w jednomandatowych okręgach wyborczych, w systemie większości względnej (First Past The Post). Oznacza to, iż ten kandydat, który otrzyma największą liczbę głosów w danym okręgu wyborczym (w przypadku wyborów na senatora jest to stan), wygrywa wybory. Zgodnie z prawem Duvergera prowadzi to do wykształcenia się systemu dwupartyjnego, co skutecznie pozbawia przed-

${ }^{1}$ Część stanów organizuje wybory stanowe i lokalne w tym samym dniu co wybory federalne. Ma to przede wszystkim na celu zwiększenie frekwencji wyborczej. Istnieje grupa stanów, które przeprowadzają wybory w tzw. off-year, czyli roku, w którym nie odbywają się żadne wybory. Są to Wirginia, Kentucky, New Jersey, Missisipi oraz Luizjana, zaś wybory dotyczą zarówno legislatur stanowych, jak i wyborów na gubernatorów. W dwóch ostatnich stanach kadencja legislatur jest czteroletnia, zaś wybory na gubernatorów odbywają się rok przed wyborami prezydenckimi (pobodnie jest w Kentucky). W Wirginii i New Jersey wybory na gubernatorów odbywają się rok po wyborach prezydenckich. Dodatkowe wybory, niewynikające $\mathrm{z}$ kalendarza wyborczego, organizowane są w wyniku powstałych wakatów na stanowiskach. Wybory uzupełniające zarówno do Izby Reprezentantów, jak i Senatu zarządza gubernator, zgodnie z art. I, sec. 2, kl. 4 oraz Poprawką XVII, sec. 2 z 1913 r. Szerzej zob. w: NCSL's StateVote 2010 Election Results, „State Legislature Magazine”, http://www.ncsl.org/tabid/21253/default.aspx, stan Wirginia, http://www.thegreenpapers.com/slg/VA.html, stan Kentucky, http://www.thegreenpapers.com/slg/KY.html, stan Mississippi, http://www.thegreenpapers.com/slg/ MS.html, stan Luizjana, http://www.thegreenpapers.com/slg/LA.html, stan New Jersey, http://www. thegreenpapers.com/slg/NJ.html, M. McLaughlin, Voter turnout at record low in off-year US election, 5.11.1999, http://www.wsws.org/articles/1999/nov1999/elec-n05.shtml, odczyt z dn. 29.11.2012. 
stawicieli partii trzecich szansy na udział w procesie elekcyjnym ${ }^{2}$. Konstrukcja systemu również zniechęca wyborców do udzielania partiom trzecim poparcia z obawy przed zmarnowaniem głosu na kandydata, który jest pozbawiony faktycznej szansy na wygranie mandatu. Co jeszcze istotniejsze, wyniki wyborów w analizowanym systemie są zwykle bardziej „zdeformowane” niż w systemie proporcjonalnym, co prowadzi do wystąpienia zjawiska zbytniej nadreprezentacji oraz niedoreprezentowania znaczącej części wyborców³ ${ }^{3}$ Rozbieżność pomiędzy procentem zdobytych przez partie głosów a odsetkiem otrzymanych przez nie mandatów mierzona jest indeksem głosów zmarnowanych, który w wyborach do Izby Reprezentantów wynosi średnio $34 \%{ }^{4}$, oraz indeksem reprezentatywności wynoszącym ok. $29 \%$.

System większości względnej nie jest już tak popularny na szczeblu lokalnym. Tradycja systemu proporcjonalnego znana jest w Stanach Zjednoczonych od końca XIX wieku, głównie za sprawą Ligi Proporcjonalnej Reprezentacji, jak i Ruchu Progresywistów ${ }^{6}$. Pierwszym miastem i zarówno pionierskim stanem, które przyjęło system proporcjonalny (system głosu przechodniego, Single Transferable Vote, zwany również Ranked-Choice Voting ${ }^{7}$ ), było Ashtabula w sta-

2 M. Duverger, Political Parties: Their Organisation and Activity in the Modern States, London 1965, s. 217.

3 Teza ta poparta jest sformułowanym w 1909 r. prawem sześcianu (cube law) J.P. Smitha, które głosi, że „proporcja mandatów uzyskanych przez dwie partie jest sześcianem proporcji zdobytych przez nie głosów”. Z prawa tego wynika, iż indeks proporcjonalności w systemie większościowym jest mniejszy niż w systemie proporcjonalnym i wynosi średnio 80 do $94 \mathrm{w}$ drugim z systemów. M. Duverger, op.cit., s. 332; D. Urwin, Electoral Systems, Bergen 1977, s. 9; R. Herbut, Systemy partyjne $w$ Europie Zachodniej, Systemy partyjne w Europie Zachodniej - ciagłość i zmiana. Studium porównawcze, Wrocław 1996, s. 128.

${ }^{4}$ Jest to odsetek głosów oddanych na kandydata, który przegrał wybory. Liczba ta jest średnią w wyborach do Izby Reprezentantów w latach 1992-2010. FairVote, U.S. Profile, Dubious Democracy 1982-2010, http://www.fairvote.org/u-s-profile-2010/\#.T7X3PdXYZCc, odczyt z dn. 31.11.2012. Szerzej zob. B. Szklarski, Wyborcy, partie i Kongres - słabości i zalety amerykańskiego systemu wyborczego, [w:] Jak wybierać naszych przedstawicieli do Sejmu? System wyborczy większościowy, czy proporcjonalny?, red. I. Rycerska, Kielce 2004.

${ }^{5}$ Jest to odsetek wyborców uprawnionych do głosowania oddających głos na kandydata, który wygrał wybory do Izby Reprezentantów. W 2010 r. najwyższy odsetek jest na Alasce (35.5\%), zaś najniższy w Oklahomie (20.5\%) i w Utah (20.2\%). FairVote, U.S. Profile, Dubious Democracy 1982-2010, op.cit.; Representation Index, http://www.fairvote.org/representation-index\#.T7X4RtXYZCc, odczyt z dn. 31.11.2012.

${ }^{6}$ Szerzej zob. w: D.J. Amy, The Forgotten History of the Single Transferable Vote in the United States, „Representation” Winter 1996/7, 34, nr 1.

7 Szczegółowy mechanizm przeliczania głosów na mandaty zob. w: J. Haman, Demokracja, decyzje, wybory, Warszawa 2003, s. 152-153. 
nie Ohio. W kolejnych latach następne miasta w stanie, $\mathrm{w}$ tym m.in Toledo, Hamilton, Cincinnati i Cleveland, zmieniły system głosowania na bardziej reprezentatywny i odpowiadający preferencjom wyborców. Największym osiągnięciem Ruchu było wdrożenie systemu w mieście Nowy Jork oraz w siedmiu miastach w stanie Massachussetts. Łącznie około 20 miast organizowało wybory w systemie proporcjonalnym. W następnych latach miasta zaczęły odchodzić od systemu proporcjonalnego i zastępowały go systemem większościowym. Przyczyną było m.in. niezadowolenie lokalnych bossów partyjnych z powodu utraty wpływów (powstał system wielopartyjny), rosnący antagonizm wobec mniejszości afroamerykańskiej (pojawili się czarnoskórzy reprezentanci) czy strach przed komunizmem (w Nowym Jorku działała Partia Komunistyczna, istniało więc niebezpieczeństwo wyboru komunistycznego reprezentanta) ${ }^{8}$. Jedynym miastem, które zachowało system proporcjonalny od 1941 roku, było Cambridge w Massachusetts.

Od lat osiemdziesiątych XX wieku dostrzegalny jest trend powrotu bądź rozprzestrzeniania się systemu proporcjonalnego w wyborach lokalnych. Przyczyna leżała w rosnącej populacji mniejszości rasowych, które w systemie większościowym były niedoreprezentowane bądź pozbawione swojego przedstawicielstwa. Promocją reformy systemu i edukacją społeczną zajęły się organizacje, takie jak: National Black Caucus of State Legislators (projekty edukacji afroamerykańskich legislatorów), Common Cause (Deceptive Practices 2.09), the League of Women Voters (projekt VOTE411 10 ), the League of United Latin American Citizens (LULAC), National Association for the Advancement of Colored People (NAACP), the Mexican American Legal Defense and Educational Fund (MELDEF). Ich wsparcie merytoryczne przyczyniło się do implementacji systemu kumulacyjnego w mieście Amarillo w Teksasie, będącego obecnie największym miastem, stosującym ów system w wyborach lokalnych. W 2000 roku Southern Center for Studies rozpoczął projekt edukacyjny skierowany do czarnoskórych wybieralnych urzędników, jak również tradycyjnie afro-amerykańskich colle-

8 R.J. Kolesar, Communism, Race, and the Defeat of Proportional Representation in Cold War America, Ohio 1996, s. 4-5.

9 Projekt informacyjny mający na celu ukrócenie praktyk podawania fałszywych informacji na temat terminu i sposobu głosowania. Common Cause, Deceptive Practices 2.0: Legal And Policy Responses, http://www.commoncause.org/atf/cf/\%7Bfb3c17e2-cdd1-4df6-92be-bd4429893665\%7D/ DECEPTIVE_PRACTICES_REPORT.PDF, odczyt $\mathrm{z}$ dn.31.11.2012.

${ }^{10}$ League of Women Voters debut new Voters Guide on website, http://amarillo.com/lifestyle/our-town/2012-04-30/league-women-voters-debut-new-voters-guide-website, odczyt z dn. 31.11.2012. 
geów i uniwersytetów, w którym uświadamiano mniejszości rasowe o zaletach systemu proporcjonalnego.

Istnieją trzy modyfikacje głosowania proporcjonalnego: głosowanie kumulacyjne (cumulative vote), ograniczone (limited vote) oraz pojedynczy głos przechodni (Single Transferable Vote zwany również Ranked-Choice Voting) ${ }^{11}$.

W systemie kumulacyjnym wyborca dysponuje tyloma głosami, ilu jest kandydatów. Swoje głosy może on bądź rozdzielić pomiędzy wybranych kandydatów, bądź udzielić poparcia tylko jednemu z nich (głosowanie skumulowane). Mandat uzyskuje ten kandydat, który uzyskał kwotę Droopa ${ }^{12}$.

W systemie głosowania ograniczonego wyborca może oddać głos na dowolną liczbę kandydatów z okręgu, lecz musi ona być mniejsza od liczby równej ilości mandatów do obsadzenia. W ten sposób wyborca może podzielić swoje preferencje pomiędzy kandydatów z różnych ugrupowań politycznych lub oddać głos jedynie na najbardziej preferowanego kandydata. System ten może zawierać również tzw. próg „wykluczenia” (threshold of exclusion), czyli minimalną liczbę głosów wyborców, jaka przy odpowiedniej strategii gwarantuje zdobycie jednego mandatu ${ }^{13}$.

Natomiast w systemie pojedynczego głosu przechodniego wyborca posiada tylko jeden głos, który przeznacza na konkretnego kandydata, według własnej preferencji. Ponadto może on dokonać, w liczbie odpowiadającej liczbie mandatów, kolejnych wyborów, szeregując listę z nazwiskami. Procedura przeliczania głosów na mandaty jest wielostopniowa i rozpoczyna się od ustalenia kwoty Droopa, będącej liczbą głosów, jaką należy zdobyć, by otrzymać mandat. Przeliczenie głosów na mandaty następuje od pierwszego miejsca, jakie dani kandydaci otrzymali na uszeregowanej liście. Jeśli kandydat, który otrzymał mandat, miał więcej głosów, niż wymagała tego kwota, jego „nadwyżkowe” głosy oddane zostają na kolejnego kandydata $\mathrm{z}$ listy. W przypadku, gdy pozostają nieobsadzone mandaty, przenosi się „nadwyżkowe” głosy na kandydatów z drugiego miejsca. Jeśli do uzyskania mandatu brakuje głosów, to skreśla się tych kandydatów, którzy znaleźli się na ostatnim miejscu na liście, a następnie sprawdza, czy uzyskali oni

11 B. Michalak, Większościowy czy proporcjonalny. Spór o kształt systemu wyborczego, „Współczesne Dialogi Polityczne" 2004, nr 3-4.

12 Kwota Droopa to suma wszystkich ważnie oddanych głosów na wszystkich kandydatów/listy w okręgu podzielona przez liczbę mandatów, która jest do obsadzenia w danym okręgu (plus jeden). Wynik jest zaokrąglany w dół. B. Michalak, A. Sokala, Leksykon prawa wyborczego i systemów wyborczych, Warszawa 2010, s. 48-49, 69.

13 J. Haman, op.cit., s. 164. 
kwotę q. Procedurę powtarza się aż do chwili rozdzielenia wszystkich mandatów. Omawiany system wymaga od kandydatów, by szukali poparcia nie tylko wśród zwolenników swojej partii, lecz również wśród wyborców głosujących na ich rywali politycznych. Wyborca może bowiem wskazać na kolejnych miejsca swojej listy preferencji kandydatów z innych partii politycznych, zwiększając tym samym ich szanse na sukces wyborczy. System ten uznany jest za najwierniej przekładający proporcjonalnie głosy na mandaty, łączy bowiem głosowanie proporcjonalne $\mathrm{z}$ wyborami konkretnych kandydatów. Należy podkreślić, iż wyborca dysponuje dużą autonomią działania w zakresie udzielenia poparcia określonym kandydatom. Celem takiego zabiegu jest „elekcja zespołu najbardziej preferowanych kandydatów przez możliwie największa część kandydatów”"14.

Obecnie szacuje się, iż ponad 200 wyborów na szczeblu lokalnym odbywa się $\mathrm{w}$ jednym z systemów głosowania proporcjonalnego ${ }^{15}$.

Przykładem zjawiska powrotu do uprzednio stosowanego systemu jest stan Illinois, w którym w latach 1870-1980 przedstawiciele do stanowej Izby Reprezentantów wybierani byli za pomocą głosowania kumulacyjnego. W ten sposób mniejszość afroamerykańska miała zapewnione swoje przedstawicielstwo w niższej izbie stanowej legislatury ${ }^{16}$. Dodatkowo rada miejska w mieście Peoria w stanie Illinois obecnie także jest wybierana w omawianym systemie wyborczym. Teksas jest natomiast świetnym przykładem stanu, w którym wzrasta liczba miast stosujących głosowanie kumulacyjne. Obecnie w 17 miastach wybory do rady miasta i w 35 do rady szkolnej odbywają się w systemie kumulacyjnym. System ten jest także stosowany w wyborach do rady miasta, powiatu i rady szkolnej w niektórych miastach w Alabamie, Płd. Dakocie czy Teksasie, a także w stanie Zach. Wirginia w wyborach do komisji rewizyjnej, zajmującej się kartą miejską (Charter Review Commissions) ${ }^{17}$.

14 Ibidem, s. 152-153.

15 R. Richie, D.J. Amy, F. McBride, How Proportional Representation Can Empower Minorities and the Poor, November/December 2000, https://www.mtholyoke.edu/acad/polit/damy/articles/empower. htm, odczyt z dn. 29.11.2012.

16 Partycypacja polityczna Afroamerykanów była zapewniona przez cały wspomniany okres. Dodatkowo w latach 1966-1980 średnia reprezentacja wspomnianej mniejszości wynosiła 14 osób (na 118 reprezentantów). Brak jest danych dotyczących reprezentacji mniejszości rasowych po zmianie systemu na większościowy. Black Representation Under Cumulative Voting in IL, http://archive.fairvote.org/?page $=419$, odczyt $\mathrm{z}$ dn. 29.11.2012.

17 FairVote, Communities in America Currently Using Proportional Voting, http://archive.fairvote. org/?page=2101, odczyt z dn. 29.11.2012. 
W wyborach lokalnych do rad szkolnych i komisji hrabstwa w stanach Alabama (22 miasta), Płn. Karolina (8 miast), Pensylwania (Filadelfia), Connecticut (Hartford), jak również w wyborach do rady miasta Dystryktu Kolumbia elekcje odbywają się w systemie głosowania ograniczonego. Stany Alabama i Płn. Karolina wdrożyły ten sam system w 1987 roku w celu rozwiązania ponad 30 spraw związanych z reprezentacją mniejszości rasowych. System ten jednak nie ma szeroko propagowany przez organizacje zajmujące się reformą systemu wyborczego.

Ostatni wspomniany system, pojedynczy głos przechodni, pomimo niezwykle skomplikowanej metody przeliczania głosów na mandaty funkcjonuje od 1941 roku w Cambridge w Massachusetts, w mieście Nowy Jork, w wyborach do rad szkolnych, czy w Utah w wyborach do stanowego Senatu. Obecnie w Massachusetts działa ruch Citizens for Voter Choice, który wspiera wdrożenie owego systemu w większości miast w stanie ${ }^{18}$. Również na szczeblu federalnym dostrzec można propagatorów reformy systemu wyborczego. Od 1995 roku reprezentantka z Georgii Cynthia McKinney zgłasza projekt ustawy Voters' Choice Act, zezwalający mieszkańcom stanów na głosowanie na przedstawicieli do Izby Reprezentantów w systemie pojedynczego głosu przechodniego. W 1999 roku kongresman z Płn. Karoliny Melvin Watt zgłosił dwupartyjny projekt ustawy States' Choice of Voting Systems Act. I choć znalazł on poparcie 16 reprezentantów, projekt „utknął” w komisjach ${ }^{19}$. Potrzebę modyfikacji systemu dostrzegli również prezydent Barack Obama, senator John McCain czy wielokrotny kandydat na prezydenta Ralph Nader, którzy opowiadają się za bardziej reprezentatywnym sposobem wyłaniania reprezentantów.

Jedna $\mathrm{z}$ wiodących organizacji promujących reformę systemu wyborczego jest The Center for Voting and Democracy - FairVote ${ }^{20}$; propaguje zmianę systemu elekcyjnego z większościowego na preferencyjny. Zdaniem jej przedstawicieli ów system zmaksymalizuje efektywność głosowania, zapewniając zrównoważoną do liczby oddanych głosów reprezentację w Izbie Reprezentantów, legislaturze stanowej, jak i radzie miejskiej. Tym samym organizacja działa na rzecz imple-

18 Szerzej zob.Citizens for Voter Choice, http://www.voterchoicema.org/proposal/where_its_used\# gov, odczyt z dn. 29.11.2012.

19 Bill Summary \& Status 106th Congress (1999-2000), http://thomas.loc.gov/cgi-bin/bdquery/z?d106:h.r.01173, odczyt z dn. 29.11.2012.

20 Organizacja powstała w $1992 \mathrm{r}$. Koncentruje się na podstawowych reformach strukturalnych amerykańskich wyborów, jak również prowadzi badania, analizy, treningi edukacyjne, a także organizuje konferencje. 
mentacji nowego systemu na wszystkich szczeblach wyborów (bez konieczności zmiany Konstytucji).

Głosowanie preferencyjne (alternative vote), nazywane również głosowaniem $\mathrm{z}$ bezpośrednią dogrywką (IRV, instant run-off voting), polega na tworzeniu przez wyborcę listy preferencji kandydujących osób (może on wskazać jedną osobę). Inaczej mówiąc, wyborca otrzymuje listę z nazwiskami kandydatów, którą wypełnia, stawiając kolejne numery koło ich nazwisk. Liczba preferencji zależna jest od liczby kandydatów w danym okręgu wyborczym. Wygrywa kandydat, który uzyskał bezwzględną liczbę głosów ( $50 \%+1$ głos). W przypadku, gdy żadna z osób kandydujących nie uzyskała wymaganej liczby głosów, następuje podział głosów kandydata, który uzyskał najmniej głosów w pierwszej preferencji, zaś jego nazwisko zostaje skreślone z listy. „Zabrane” głosy są rozdzielane pomiędzy pozostałymi kandydatami, według kolejnych preferencji. Sytuację powtarza się aż do otrzymania bezwzględnej większości głosów przez jednego $\mathrm{z}$ kandydatów ${ }^{21}$. Istotny jest fakt, iż są to wybory jednoturowe. Praktyka systemu wskazuje, iż w przypadku braku natychmiastowego wyniku wybory wygrywa kandydat, który znajdował się na drugim lub trzecim miejscu na liście preferencji.

Głosowanie preferencyjne jest niezwykle popularne wśród organizacji (m.in. American Political Science Association, czy American Mensa), uniwersytetów oraz collegéów (m.in. Harvard, Duke, Emory, John Hopkins, Princeton czy Georgetown), które stosują ów system do wyboru rad studenckich bądź władz uczelnianych. Od lat dziewięćdziesiątych władze lokalne w stanach Nowy Jork (miasto Nowy Jork oraz Yonkers), Waszyngton (hrabstwo Pierce), Michigan (Ann Arbor), Kolorado (Aspen), Vermont (Burlington) Płn. Karolina (Cary) są wybierane w systemie preferencyjnym.

Inicjatywą aktywistów z FairVote system ten został wdrożony i z powodzeniem działa w wyborach lokalnych (na burmistrza, członków rady miejskiej) w sześciu stanach: Kalifornii (w miastach San Francisco, Oakland, San Leandro, Berkeley), w Minnesocie (Minneapolis, St. Paul), w Maryland (Takoma Park), w Kolorado (Telluride), w Maine (Portland), w Płn. Karolinie (Hendersonville) ${ }^{22}$. Jest on także stosowany w wyborach na przedstawicieli stanowych i federal-

21 D. Urwin, op.cit., s. 15.

22 System ten stosowany jest obecnie w Memphis w Tennessee, zaś pierwsze wybory w nowym systemie odbedą sie w 2013 r. FairVote, Where Instant Runoff Is Used, http://www.fairvote.org/where-instant-runoff-is-used\#.T7c74NXYZCc, odczyt z dn. 29.11.2012. 
nych, jako forma głosowania zamorskiego w Płd. Karolinie, Illinois (Springfield), Luizjanie i w Arkansas.

Praktyka systemu pokazała, iż nastąpiło zwiększenie liczby kandydatów na listach wyborczych, a poprzez to wzrosła konkurencyjności wyborów. Ponadto kampanie wyborcze przybrały mniej negatywny charakter, głównie ze względu na dużą liczbę kandydatów, jak również dzięki budowaniu koalicji pomiędzy kandydatami jeszcze w czasie kampanii wyborczych. Poza tym zaobserwowano zwiększenie frekwencji mniejszości rasowych i etnicznych, jak również rangowanie (wybieranie) kandydatów pochodzących z mniejszości etnicznych i rasowych. W końcu koszty organizacji wyborów zostały zredukowane, zwłaszcza w miastach, gdzie obowiązywał system wyborów dwutorowych.

Jak dotąd jest to najsprawniej działający ruch reformatorski, którego ambicją jest przekształcenie wyborów na system preferencyjny na wszystkich szczeblach, z Izbą Reprezentantów włącznie.

\section{WYBORY PREZYDENCKIE}

Wybory na prezydenta mają charakter dwustopniowy ${ }^{23}$. Oznacza to, że w przewidzianym dniu wyborów (pierwszy wtorek po pierwszym poniedziałku listopada) wyborcy, w głosowaniu powszechnym, głosują na elektorów reprezentujących danego kandydata na prezydenta. Głosowanie, prócz stanów Maine i Nebraski ${ }^{24}$, oparte jest na systemie większościowym, co sprawia, iż kandydaci nie zawsze otrzymują proporcjonalne do liczby otrzymanych głosów poparcie elektorskie

${ }^{23}$ Szerzej zob. R.R. Ludwikowski, A. Ludwikowska, Wybory prezydenckie w USA na tle porównawczym, Warszawa 2009.

${ }^{24}$ W stanach tych dwóch elektorów jest wybieranych w głosowaniu większościowym, zaś pozostali (dwóch w Maine i trzech w Nebrace) w tzw. systemie proporcjonalnym/dystryktowym (Congressional District Method), który polega na podziale stanu na okręgi odpowiadające liczbie pozostałych elektorów i przydzieleniu elektorów, w zależności od poparcia otrzymanego w okręgach. Pozostałe dwa głosy elektorskie otrzymuje kandydat, który otrzymał większość głosów w skali całego stanu. Choć system ten uznawany jest za bardziej reprezentatywny, to od czasu zmiany metody przeliczania głosów (od 1969 r. w Maine i 1992 r. w Nebrasce) zdarzył się jeden przypadek proporcjonalnego rozłożenia głosów (Nebraska 2008 r.). Secretary of State, Electoral Votes, http://www.sos.ne.gov/elec/2008/ ElectNight/electoral.htm; Maine.gov, Maine Electors Convene and Cast Ballots for President, http:// www.maine.gov/sos/news/electorsvote.html; 2008 Presidential Election Electoral Vote Data, http:// uselectionatlas.org/RESULTS/, odczyt z dn. 29.11.2012. 
(casus wyborów prezydenckich w 2000 roku) ${ }^{25}$. Następny etap - głosowanie elektorów (tzw. Kolegium Elektorskie ${ }^{26}$ ) - odbywa się w pierwszą środę po pierwszym poniedziałku grudnia i jest formalnością, bowiem elektorów, w zależności od stanu, wybierają konwencje partyjne bądź zarejestrowani wyborcy.

Kolegium Elektorskie jest powszechnie krytykowanym ciałem, głównie ze względu na potencjalne zagrożenia wynikające z jego funkcjonowania. Pierwszym problemem, na jaki należy zwrócić uwagę, jest możliwość zmiany decyzji przez elekta w kwestii wyboru kandydata na prezydenta (tzw. Faithless Electors). Choć od 1952 roku (sprawa Ray v. Blair, 343 U.S. 214 ${ }^{27}$ ) elektorzy są zobowiązani do głosowania na kandydata, na którego się zdeklarowali, zdarzają się umyślne bądź pomyłkowe przypadki zagłosowania na kandydata przeciwnego. Zdarzenia takie miały miejsce w latach: 1968, 1972, 1976, 1984, 1988, 2000 i 2004.

Obecnie 29 stanów i Dystrykt Kolumbia ${ }^{28}$ posiadają regulacje prawne odnoszące się do ukarania elektora za niewywiązanie się z nałożonego na niego obowiązku zagłosowania zgodnie z deklaracją ${ }^{29}$. Oznacza to tym samym, że nadal w 21 stanach nie ma obowiązku i prawnych uregulowań kontroli elektorów przez prawo stanowe.

Kolejną kwestią jest możliwość wybrania prezydenta jedynie przez 12 stanów, co oznacza, że uwaga kandydatów jest skupiona na prowadzeniu kampanii głównie w tych stanach, jak również w stanach, które nie mają ugruntowanego elektoratu (swing states lub purple states) ${ }^{30}$. Zatem do wygrania wyścigu o fotel prezydencki

25 W głosowaniu powszechnym Bush otrzymał 50460110 głosów wyborców, podczas gdy A. Gore 51003 926, zaś w Kolegium Elektorskim rozkład głosów kształtował się następująco: 271 do 266. 2000 Presidential General Election Results, http://uselectionatlas.org/RESULTS/index.html, odczyt z dn. 29.11.2012. Szerzej zob. R.R. Ludwikowski, Aspekty prawne ostatnich wyborów prezydenckich w Stanach Zjednoczonych, „Państwo i Prawo” 2001, z. 4, s. 33.

${ }^{26}$ Ciało to składa się z 538 elektorów (liczba ta pochodzi z dodania liczby reprezentantów i senatorów w danym stanie, trzech dodatkowych elektorów jest z Dystryktu Kolumbia), wybieranych w drodze wyborów przez wyborców (partie wskazują kandydatów). Szerzej na temat sposobu funkcjonowania Kolegium Elektorskiego zob. w: Konstytucja, sek. 1, art. II, Poprawka XII (1804), Poprawka XIV (1868), Poprawka XXIII (1961). Szerzej na temat idei powstania Kolegium Elektorskiego, zob. L. Wilmerding, The Electoral College, Rutgers 1958.

${ }^{27}$ Ray v. Blair, 343 U.S. 214 (1952).

28 Szerzej zob. S. Domaradzki, Prawa wyborcze mieszkańców Dystryktu Kolumbia - węzeł gordyjski amerykańskiej demokracji, [w:] Wybory w USA - z zagadnień teorii i praktyki, red. B. Bednarczyk, Kraków 2008.

${ }^{29}$ Legal Requirements or Pledges, http://www.archives.gov/federal-register/electoral-college/laws. html, odczyt z dn. 29.11.2012.

30 Nazwa „niezdecydowane”, „chwiejne” bądź „purpurowe” stany odnosi się do tych stanów, w których elektorat jest wymieszany i istnieje możliwość wygrania wyborów przez demokratę lub 
w 2000 roku wystarczyło zdobycie 21835615 głosów (na 105417475 wszystkich oddanych), zaś w 2008 roku 39908351 głosów (na 131338626 wszystkich oddanych) ${ }^{31}$. W dodatku, jak wyliczyli R. Richie i P. Fidalgo, w ostatnich dwóch miesiącach kampanii w 2008 roku żaden z głównych kandydatów nie prowadził kampanii w 32 stanach, zamieszkałych przez $61,8 \%$ ludności ${ }^{32}$. Taka konstrukcja systemu może wpływać negatywnie na frekwencję wyborczą, bowiem wyborcy z danych stanów mogą mieć świadomość, iż ich głos nie ma dużego znaczenia $\mathrm{w}$ wyścigu wyborczym ${ }^{33}$. Ponadto system ten umożliwia wybranie prezydenta popieranego przez mniejszość, jak to miało miejsce w 2000 roku $^{34}$.

W końcu konstrukcja systemu sprawia, że Kolegium faktycznie nie odzwierciedla woli narodu. Przykładem są kandydaci niezależni bądź z partii trzecich (G. Wallace ${ }^{35}$, J. Anderson ${ }^{36}$, R. Perot ${ }^{37}$ ), którzy otrzymali poparcie wyborców

republikanina. Termin ten może odnosić się również do wyników wyborów - stany „chwiejne” przechylają szalę zwycięstwa na któregoś z kandydatów. Do stanów „purpurowych” zalicza się stany: Iowa, Ohio, Indianę, Missouri, Florydę, Georgię, Płn. Karolinę, Wirginię, Montanę i Kolorado (łącznie 114 głosów elektorskich). Strategia nakierowana na kampanię w tych stanach stała się powszechna od 1968 r. Szerzej zob. C.J. Nelson, Grant Park, The Democratization of Presidential Elections, 1968-2008, Washington DC 2011, s. 59-72.

31 Zatem pozostałe 28624495 głosów oddanych na Busha i 29591077 oddanych na Obamę nie miało znaczenia dla wygranej Busha i Obamy. Obliczenia własne, na podstawie 2000 Presidential General Election Data - National, 2008 Presidential General Election Results, http://uselectionatlas. org/RESULTS/ (29.11.2012).

32 R. Richie, P. Fidalgo, The Swing States of America Has the Electoral College Pushed President Obama Away from a 50-State Strategy?, 25.06.2009, http://archive.fairvote.org/?page=27\&pressmode=showspecific\&showarticle=254, odczyt z dn. 29.11.2012.

33 Tezę tę potwierdzają badania m.in. S.C. McKee, The Electoral College, Mobilization, and Turnout in the 2000 Presidential Election, „American Politics Research” 2005, September, vol. 33, nr 5, s. 700-725; D.M. Cann, B. Cole, Does the Electoral College Depress Voter Turnout? Strategic Campaigning, Closeness, and Voter Mobilization in U.S. Presidential Elections, „Electoral Studies” June 2011, vol. 30, s. 344-352.

${ }^{34}$ G.W. Bush uzyskał 47,87\% głosów powszechnych, zaś A. Gore 48,38\%. 2000 Presidential General Election Result, op.cit.; Legal Requirements or Pledges, op.cit.

35 Startujący w wyborach prezydenckich w 1968 r. otrzymał 13,5\% głosów w głosowaniu powszechnym i 46 głosów w głosowania elektorskim (w Luizjanie, Arkansas, Mississippi, Georgii i Alabamie).

${ }^{36}$ W 1980 r. Anderson ubiegał się o fotel prezydenta. Zdobył 6,6\% głosów w głosowaniu powszechnym i ani jednego głosu w Kolegium Elektorskim.

37 „Rekordzista” w tej kwestii R. Perot w 1992 r. nie otrzymał żadnego głosu elektorskiego, choć jego poparcie wyborcze osiągnęło niemal 19\%. 
w głosowaniu powszechnym, lecz nie zdobywają żadnego głosu elektorskiego. W dodatku waga głosów pomiędzy stanami dużymi i małymi nie jest równa ${ }^{38}$.

Dostrzegając wady istniejącego systemu wyborczego i brak należytej reprezentatywności wyborców, w Stanach Zjednoczonych rozpoczęto debatę nad zmianą systemu wyboru prezydenta na bardziej reprezentatywny. Bodźcem do zmian były wybory w 1968 roku i wspomniane wydarzenia. Do najbardziej popularnych propozycji reform zalicza się przekształcenie systemu elekcji prezydenta w: (1) ułamkowy system proporcjonalny (fractional proportional allocation of votes); (2) system dystryktowy; (3) wybory bezpośrednie, większościowe, z zachowaniem Kolegium Elektorskiego.

Pierwsza metoda, jako propozycja Poprawki do Konstytucji, zaproponowana została po wyborach w 1968 roku $^{39}$. Polega na podzieleniu głosów elektorskich proporcjonalnie do poparcia udzielonego kandydatom $\mathrm{w}$ danym stanie $\mathrm{e}^{40}$. System ten niewątpliwie podniósłby konkurencyjność wyborów, co zachęciłby kandydatów, zwłaszcza z partii trzecich bądź niezależnych, do ubiegania się o urząd, jak również podniósłby frekwencję wyborcząa․ Co więcej, zwiększyłby reprezentatywność wyborów w poszczególnych stanach. Jednakże matematyczne wyliczenia pokazały, iż system ten osłabiłby zasadę równości głosów u 95\% wyborców, zaś waga głosu wyborcy z Alaski byłaby pięć razy większa niż waga głosu mieszkańca stanu Nowy Jork ${ }^{42}$.

${ }^{38}$ Nadreprezentowane są małe, mniej liczne stany. Szerzej zob. w: FairVote, State Population vs. Electoral Vote, http://archive.fairvote.org/index.php?page=985, odczyt z dn. 29.11.2012; S.J. Wayne, Is This Any Way to Run a Democratic Election?: Debating American Electoral Politics, Boston 2003.

39 L.D. Longley, A.G. Braun, The Politics of Electoral College Reform, part 2, New Haven 1972. Longley opisuje działalność Constitutional Amendment Subcommittee of the Senate Judiciary Committee w latach 1969-1971.

${ }^{40}$ Inaczej mówiąc, kandydat, który otrzymał 45\% głosów wyborców i zajął drugie miejsce w okręgu, otrzymuje 45\% głosów elektorskich, zamiast 0 , jak to ma miejsce w systemie większościowym. Symulację wyborów z 2000 r. w tym systemie przeprowadził zespół pracujący nad raportem Every Vote Equal. Wynikało z niej, iż wybory wygrałby A. Gore. Szerzej zob. J.R. Koza, B. Fadem, M. Grueskin, M.S. Mandell, R. Richie, J.F. Zimmerman, A State-Based Plan for Electing the President by National Popular Vote, Los Altos 2008, s. 106-109.

${ }^{41}$ Wybory konkurencyjne (marginalne, reprezentatywne) to takie, w których różnica w wynikach dwóch kandydatów, którzy otrzymali największą liczbę głosów, nie przekracza 10\%. Obecnie w 37 stanach wybory nie mają charakteru konkurencyjnego. Legal Requirements or Pledges, op.cit.

42 L.D. Longley, J.D. Dana Jr, The Bias in Electoral College in 1990s, „Polity” Autumn 1992, vol. 25, nr 1, s. 123-145; J. Banzhaf III, A Mathematical Analysis of the Electoral College, „Villanova Law Review" Winter 1968, vol. 13, s. 303-348. 
Druga propozycja - wyborów opartych na systemie dystryktowym - była autorstwa senatora K. Mundta z Płd. Karoliny. Głównym jej zamierzeniem była zmiana alokacji głosów poprzez ich rozłożenie pomiędzy dystrykty, zaś kandydat, który uzyskał większość głosów, miał otrzymać dwa pozostałe głosy elektorów ${ }^{43}$. Ponadto poprawka nakładała na elektorów obowiązek złożenia „przysięgi wierności” wobec wybranego kandydata. Kolejna propozycja dotyczyła samej formy głosowania - nawet po zmianie preferencji elektora jego głos miał być liczony zgodnie ze złożoną deklaracją. Projekt również został odrzucony z powodu złamania zasady równości głosów we wszystkich stanach. Waga głosów w stanach o małej liczbie ludności, takich jak: Alaska, Wyoming czy Newada, była dwa i pół razy większa niż ludności w stanie Kalifornia, czy Nowy Jork ${ }^{44}$. Prócz tego oparcie wyborów prezydenckich na dystryktach kongresowych sprawiłoby, iż z większą atencją analizowano by proces redystrykcji, który już obecnie uważany jest za niezwykle upolityczniony ${ }^{45}$.

Trzecim projektem Poprawki do Konstytucji z 1969 roku był plan wyborów bezpośrednich, opartych na równości głosów wszystkich obywateli ${ }^{46}$. Projekt został zablokowany w Senacie procedurą obstrukcji (filibuster), zaś głównym argumentem przeciwników było, że wyboru prezydenta będą dokonywać duże stany, co jak dowodzi J. Banzhaf III, nie było prawdą ${ }^{47}$. Najnowszy projekt, tym razem w formie ustawy National Popular Vote (HB 585), omija żmudną procedurę zgłaszania Poprawek do Konstytucji. Jak dowodzą przedstawiciele projektu

43 Propozycja nie doczekała się akceptacji w Kongresie, lecz wspomniane już stany Maine i Newada z powodzeniem realizują jej modyfikację - system dystryktów kongresowych.

${ }^{44}$ Dodatkowo system ten zaniżał wagę głosów ludności w 34 stanach, czyli u 93\% uprawnionej do głosowania populacji. Zob. symulację wyborów w systemie dystryktowym: J. Banzhaf III, op.cit., s. 331.

45 Szerzej zob. S. Issacharoff, P.S. Karlan, Where to Draw the Line? Judicial Review of Political Gerrymanders, „University of Pennsylvania Law Review” 2004, November, vol. 153, nr 1, Symposium: The Law of Democracy, s. 541-578.

46 Plan był autorstwa B. Bayh (D-Indiana), przedstawiony jako Rezolucja wspólna nr 1 w czasie 91. sesji Kongresu w 1969. Congressional Record, 18.09.1969, s. 25,990-25,991.

47 J. Banzhaf III, op.cit., s. 332. Kolejny projekt poprawki poddano pod obrady w 1979 r. Tak R. Dole przekonywał do głosowania za projektem: „Kandydaci będą wkrótce zdawać sobie sprawę, że głosy z małych stanów mają tę samą wagę, co głosy ze stanów dużych. To jest dla mnie jedna z głównych zalet wyborów bezpośrednich. Każdy głos posiada równe znaczenie. Bezpośrednie wybory dadzą kandydatom motywację do prowadzenia kampanii w stanach, które są postrzegane jako stany jednopartyjne. Skumulowanie ich głosów będzie istotne, a w niektórych przypadkach może nawet decydujące”. Congressional Record, 14.01.1979, s. 309. Podobne projekty poprawek były zgłaszane jeszcze w 1992 r. i w 2005 r., lecz żadna dotychczas nie spotkała się z pełną akceptacją członków Kongresu. Szerzej zob. J.R. Koza, B. Fadem, et al., op. cit., s. 115-131. 
National Popular Vote, do zmiany systemu transferowania głosów wyborców na głosy elektorów nie jest potrzebna zmiana Konstytucji ${ }^{48}$.

Zgłoszona ustawa National Popular Vote nie likwiduje Kolegium Elektorskiego, lecz pozwala na bardziej reprezentatywne przełożenie głosów na elektorów na podstawie umowy międzystanowej (Interstate Compact). Polega na zastąpieniu obecnie stosowanej zasady dotyczącej rozłożenia elektorów w poszczególnych stanach zasadą gwarantującą wybór prezydenta, mającego największą liczbę głosów we wszystkich pięćdziesięciu stanach i Dystrykcie Kolumbia $^{49}$. Propozycja została przyjęta przez dziewięć legislatur stanowych, w dwóch kolejnych ustawach została przegłosowana, w kolejnych dziesięciu została przegłosowana w jednej izbie, w pozostałych 30 stanach jest na etapie prac w komisjach ${ }^{50}$.

Wspomniane pokrótce propozycje są jedynie zarysem debaty na temat zmiany obowiązującego systemu wyboru prezydenta. Propozycja wyborów powszechnych wydaje się realną szansą nie tylko na usprawnienie procedury elekcji prezydenta, ale również na uczynienie wyborów faktycznym odzwierciedleniem głosów elektoratu. Co istotne, nastawienie społeczeństwa do

48 Konstytucja Stanów Zjednoczonych, art. II, sec. 1: „Każdy stan wyznacza w trybie określonym przez swoje ciało ustawodawcze odpowiednią liczbę elektorów”. Pośród propagatorów reformy systemu wyborów prezydenckich są m.in. FairVote, Common Cause, League of Women Voters, Brennan Center, American Civil Liberties Union, National Association for the Advancement of Colored People.

49 Głosy będą zliczone, a następnie elektorzy „wybiorą” kandydata, który uzyskał największą liczbę głosów, lecz nie w poszczególnych stanach, lecz na poziomie narodowym. W ten sposób zniwelowane będzie niebezpieczeństwo bardzo bliskich wyborów, jak również oszustw wyborczych i konieczności ponownego przeliczania głosów. Ponadto głosy wszystkich wyborców będą faktycznie równe, co zlikwiduje problem nadreprezentacji małych stanów (np. Alaski czy Dalawere, w których głos wyborcy 2,5 razy „silniejszy” niż głos wyborcy z Kalifornii). Dodatkowo też kandydaci będą prowadzili kampanie wyborcze we wszystkich stanach, a nie tylko w tzw. „chwiejących się” (swing states), czyli takich, w których rozstrzygają się wyniki wyborów. D. Walbert, Does my vote count? Understanding the Electoral College, http://www.learnnc.org/lp/media/lessons/davidwalbert7232004-02/electoralcollege.html\#5b; J. Gay, Presidential Tracker: The Orphaned States of America, 16.05.2012, http://www. fairvote.org/presidential-tracker-the-orphaned-states-of-america\#.T7ajFtXYZCc; National Popular Vote, What is ",The Agreement Among the States to Elect the President by National Popular Vote" and How Would It Work?, http://www.nationalpopularvote.com/pages/faqitem.php? $\mathrm{f}=11$, odczyt z dn. 29.11.2012.

50 Jednakże, aby weszła ona w życie, potrzeba zgody stanów o łącznej liczbie 270 głosów elektorskich (obecnie jest 132 głosy). National Popular Vote, Myths about the Constitution, http://nationalpopularvote.com/pages/answers/m1.php\#m1_1; HB 585, http://www.nationalpopularvote.com/resources/bills/NE-LB583-Bill-2011-Haar.pdf, odczyt z dn. 29.11.2012. 
zreformowania systemu jest przychylne - około 70\% społeczeństwa popiera wprowadzenie bardziej reprezentatywnego sposobu wyłaniania prezydenta ${ }^{51}$.

$\mathrm{Na}$ zakończenie należy wspomnieć o propozycjach odnoszących się do zmiany sposobu przeprowadzania prawyborów (primaries) bądź caucuses. Prawybory są organizowanym przez władze stanowe sposobem wyłaniania delegatów bądź kandydatów, którzy ubiegają się o nominację Konwencji Narodowej. Ich celem jest zbadanie popularności kandydatów przed wyborami ogólnonarodowymi. Prawybory mogą mieć charakter otwarty (uczestnik może udzielić poparcia dowolnemu kandydatowi, bez względu na przynależność partyjną) bądź zamknięty (wyborca musi wcześniej zdeklarować się, którą partię popiera $)^{52}$. Natomiast caucuses organizowane są przez partie i mają charakter zebrań partyjnych. Selekcja kandydatów bądź delegatów odbywa się na kilku poziomach, $z$ których najniższym jest poziom lokalny, a najwyższy poziom konwencji stanowej ${ }^{53}$.Zatem początkowo wyborcy, a następnie delegaci mają dłuższy czas na przyjęcie określonego stanowiska i poparcie konkretnego kandydata. Wreszcie należy wspomnieć o wyborach blankietowych, które ze względu na otwarty charakter głosowania zostały unieważnione przez Sąd Najwyższy w 2000 roku $^{54}$. Zgodnie z wykładnią sędziów prawybory otwarte również powinny zostać

51 W tym 78\% demokratów, 60\% republikanów i 73\% niezależnych. National Popular Vote, Polls Show more than 70\% Support for a Nationwide Vote for President, http://nationalpopularvote.com/ pages/polls.php\#PA_2008DEC; Survey of Political Independents, The Washington Post-Kaiser Family Foundation-Harvard University Survey Project, 3.05-3.06.2007, http://www.washingtonpost.com/ wp-srv/politics/interactives/independents/post-kaiser-harvard-topline.pdf, odczyt z dn. 29.11.2012.

52 Szerzej kwestię prawyborów, z ich podziałem zob. w: L.M. Bartels, Presidential Primaries and the Dynamics of Public Choice, Princeton University Press, Princeton 1988; B. Norrander, The imperfect primary: oddities, biases, and strengths of U.S. Presidential Nomination Politics, New York 2009.

53 Charakter caucuses jest zróżnicowany w zależności od stanów. Wyborcy głosują na delegatów na poziomie hrabstwa w sposób tajny, za pomocą podniesionej ręki bądź na podstawie zajmowanego miejsca na sali (tworzenie tzw. grup preferencyjnych). Następnie wyłonieni delegaci wybierają delegatów na poziomie dystryktu. Proces ten powtarzany jest do momentu wyselekcjonowania delegatów na konwencję stanową, która to dokonuje ostatecznej selekcji kandydatów na Konwencję Narodową. Szerzej zob. w: R.R. Ludwikowski, A. Ludwikowska, Wybory prezydenckie w USA na tle porównawczym, op.cit., s. 57-61.

${ }^{54}$ Ich ideą było połączenie systemu prawyborów zamkniętych z otwartymi. Wyborca musiał być zarejestrowany, lecz mógł dokonać selekcji kandydatów z list wszystkich partii. Propozycja ta (Proposition 198, Kalifornia) została zaskarżona przez dominujące partie, bowiem obawiały się one, iż wyborcy mogą celowo głosować na najsłabszego kandydata partii przeciwnej w celu osłabienia szans najsilniejszego. Podobne stanowisko przyjął Sąd Najwyższy w sprawie California Democratic Party vs. Jones, „wystarczą jedne wybory, w których kandydat na prezydenta wybierany przez osoby nienależące do danej partii, aby tę partię zniszczyć”. California Democratic Party vs. Jones, 530 U.S 567 (2000). 
zakwestionowane i unieważnione. Tak się jednak nie stało, czego przykładem jest orzeczenie w sprawie Washington State Grange vs. Washington State Republican Party z 2008 roku $^{55}$.

Choć proces ten wydaje się fundamentalny w przebiegu wyborów prezydenckich, dostrzegalne są negatywne zjawiska, które mogą zniekształcić faktyczne poparcie społeczne udzielane danym kandydatom. Po pierwsze, małe zaangażowanie wyborców może wpływać zarówno na jakość kandydatów, jak również reprezentatywność kandydatów ${ }^{56}$. Po drugie, stany zmieniają terminy organizacji prawyborów celem „wybicia się” w okresie nominacji i zwrócenia uwagi kandydatów na kwestie naglące $\mathrm{w}$ danym stanie ${ }^{57}$. W końcu kandydaci skupiają swoje kampanie wyborcze na „chwiejnych” stanach, bowiem to w nich rozstrzygają się wyniki wyborów. Pomijają tym samym te stany, w których mają stabilny elektorat, bądź te, w których nie mają szans na wygraną ${ }^{58}$.

Stowarzyszenie „Napraw Prawybory” (Fix The Primaries), składające się $\mathrm{z}$ dwupartyjnych reformatów, opracowało plany reformy systemu selekcji kandydatów na kandydatów na prezydenta.

Pierwszym projektem jest Plan Amerykański, polegający na pogrupowaniu stanów według kryteriów wielkości na dziesięć grup, od najmniejszych do największych ${ }^{59}$. Terminy prawyborów zostałyby podzielone na dziesięć

55 Washington State Grange vs. Washington State Republican Party, No. 06-713, (2008), http:// www.law.cornell.edu/supct/html/06-713.ZS.html, odczyt z dn. 29.11.2012.

56 Przykładowo, w 2012 r. w prezydenckich prawyborach najniższą frekwencję wyborczą odnotowano w stanie Wirginia (4.6\%), zaś najwyższą w Wisconsin (28\%). W Superwtorek prawybory odbyły się w 10 stanach, zaś średnia frekwencja wynosiła 11,5\%. Zatem reprezentatywność kandydatów jest niezwykle niska. 2012 Primary Schedule, http://www.2012presidentialelectionnews.com/2012-republican-primary-schedule/, odczyt z dn. 29.11.2012.

57 Szerzej kwestie tę opisali R.R. Ludwikowski, A. Ludwikowska, Wybory prezydenckie w USA..., op.cit., s. $73-78$.

58 Przykładowo, w 2008 r. w końcówce kampanii (wrzesień-koniec października) kandydaci na prezydenta odwiedzili cztery „huśtające się” stany ponad 89 razy, nie prowadząc tym samym kampanii w pozostałych stanach. L. Kirshner, Presidential Candidate Tracker - Oct. 29th Update, http://www. fairvote.org/presidential-candidate-tracker-oct-29th-update\#.T7yoQNVSRCcl, odczyt z dn. 29.11.2012.

59 Stany będą poszeregowane według następującego klucza: w pierwszym tygodniu prawyborów stany o łącznej sumie ośmiu okręgów będą organizować głosowanie. Oznacza to np. prawybory w New Hampshire (2 okręgów) i caucuses w Iowa ( 5 okręgów), jednakże w praktyce mogą to być dowolne stany, których łączna liczba okręgów nie przekracza ośmiu. W kolejnych odstępach dwutygodniowych dodawane są następne okręgi (w liczbie ośmiu bądź wielokrotności liczby osiem), w następującej kolejności: 16, 24, 56, 32, 64, 40, 72, 48, 80. Tym samym największe stany są rozbite na różne okresy, by nie powodować skupienia uwagi tylko na ostatnich terminach prawyborów. R. Go- 
dwutygodniowych okresów, w czasie których określona grupa stanów może przeprowadzić wybory. W ten sposób żaden stan nie mógłby „wyłamać się” i zorganizować głosowania w innym terminie. Koszty przeprowadzenia kampanii w poszczególnych stanach byłyby zatem zróżnicowane, co dawałoby szanse kandydatom niezależnym i mniej zamożnym. Plan zakłada przeprowadzenie konkurencyjnych prawyborów i wyłonienie kandydata popieranego przez większość obywateli w stanach (w ostatniej fazie prawyborów).

Drugi plan, Narodowy, polega na możliwości zagłosowania przez wyborcę na danego kandydata w ciągu pięciomiesięcznego okresu (od 1 stycznia do 30 czerwca roku wyborczego). Stany byłyby zobowiązane do miesięcznego publikowania wyników prawyborów, co dałoby wyborcy możliwość namysłu i podjęcia właściwej decyzji (a nie jak jest obecnie według „barometru” po prawyborach w New Hampshire i caucuses w Iowa). Projekt ten stawia wszystkie stany na równej szali, dając tym samym wyborcom szansę na szersze uczestnictwo w kampanii wyborczej.

Kolejny plan, Delaware, polega na pogrupowaniu stanów według wielkości i przeprowadzeniu prawyborów w czterech blokach (małe, średnie większe, największe stany). Plan został skrytykowany przez duże stany i odrzucony na Narodowej Konwencji Republikanów w 2000 roku.

Międzyregionalny projekt, autorstwa republikańskiego reprezentanta S. Levina oraz demokratycznego senatora B. Nelsona, zakłada podział stanów na sześć grup, które zostałyby uszeregowane w sześć podgrup (od A do F), wybranych w drodze losowania (w jednej podgrupie może być jeden, dwa lub trzy mniejsze stany). Wyznaczono sześć terminów prawyborów (od marca do czerwca), w czasie których stan z danej podgrupy bądź grupka mniejszych byłyby zobowiązane do przeprowadzenia głosowania. Tym samym każde prawybory dają szeroki pogląd na zakres poparcia, jakim cieszą się dani kandydaci w różnych częściach kraju. Rotacyjny charakter podgrup sprawia, iż w kolejnych wyborach znalazłyby się one na innym miejscu w grupie i dzięki temu prawybory byłyby organizowane w innym, wyznaczonym terminie ${ }^{60}$. Projekt został jednak skrytykowany, głównie ze względu na koszty, jakie będą ponosić poszczególni kandydaci, zmuszeni do krążenia po całym kraju w celu zdobycia poparcia elektoratu.

odspeed, Reforming the Presidential Primary System, 8.12.2007, http://goodspeedupdate.com/ date/2007/12, odczyt z dn. 29.11.2012.

60 Ibidem. 
Narodowe Stowarzyszenie Sekretarzy Stanów (National Association of Secretaries of State) zarekomendowało w 2000 roku regionalny plan rotacyjny, polegający na podziale kraju na cztery regiony - północny wschód, środkowy zachód, zachód i południe - mające zbliżoną liczbę elektorów w Kolegium Elektorskim. Prawybory byłyby organizowane w czterech terminach, oddzielnie dla każdego regionu, z zastrzeżeniem, iż Iowa i New Hampshire utrzymałyby swoją uprzywilejowaną pozycje „otwierających” stanów. Terminy prawyborów dla każdego z regionów byłyby rotacyjne, dając tym samym możliwość bycia pierwszym, ale i ostatnim ${ }^{61}$. Plan ten dawałby niemalże równą wagę wszystkim regionom w prawyborach, zmuszając tym samym kandydatów na zwracanie uwagi na potrzeby także mniejszych stanów. Ponadto eliminowałby „wybieganie” stanów przed szereg (tzw. frontloading) z organizacją prawyborów. Dawałby on również szansę wszystkim kandydatom na równą walkę wyborczą do końca prawyborów oraz zmniejszałby koszty kampanii, bowiem kandydat skupiałby uwagę na danym regionie (i jego problemach) i tylko po nim się poruszał. Wadą systemu jest oddzielne organizowanie głosowania w stanach Iowa i New Hampshire, bowiem kandydaci nadal prowadziliby intensywną kampanię właśnie tam, zdając sobie sprawę z roli owych stanów, jako wyznaczników wyników prawyborów. Dodatkowo rotacyjny charakter pozwoliłby przewidzieć kolejność prawyborów w poszczególnych regionach, co mogłoby spowodować, iż kandydaci prowadziliby nieoficjalną kampanię w poszczególnych stanach znacznie wcześniej. Projekt jednak znalazł uznanie Komisji Baker-Carter, zajmującej się reformą systemu wyborczego, a także został zgłoszony w formie projektu ustawy Regional Primaries Act of 2007 przez trzech senatorów: A. Klobuchar, J. Liebermana (Demokraci) oraz L. Alexandera (Republikanin) ${ }^{62}$.

Wśród zgłoszonych projektów zmiany sposobu organizacji prawyborów znalazł się również plan prof. L. Sabato. Regionalny Plan Loteryjny, bo o nim mowa, grupuje stany na cztery regiony geograficzne, przydzielając po jednym miesiącu na region do zaplanowania prawyborów (od kwietnia do lipca). Harmonogram organizacji głosowania byłby ustalany losowo w pierwszy dzień roku wyborczego. Dodatkowa loteria byłaby zorganizowana dla stanów mających

61 The National Association of the Secretary of States, Presidential Primaries in 2012 and Beyond, Report of the NASS Subcommittee on Presidential Primaries, luty 2008.

62 Projekt zatwierdziły również Rada Stanowych Rządów (The Council of State Governments) oraz Narodowe Stowarzyszenie Wicegubernatorów (The National Lieutenant Governors' Association). Pomimo dużego poparcia społecznego (prasa, politycy, władze stanowe) nie udało się przeprowadzić ustawy w Kongresie. 
czterech elektorów lub mniej celem wyznaczenia ich do organizowania pierwszych prawyborów. W ten sposób uniknęłoby się uprawianego w Iowa i New Hampshire politykierstwa ${ }^{63}$.

W końcu projekt organizacji prawyborów w jednym dniu (the One Day National Primary) we wszystkich stanach równocześnie. Został jednak poddany krytyce, bowiem dawałby przewagę kandydatom najsilniejszym w danym okresie kampanii, eliminując tym samym mniej znanych i bardziej umiarkowanych. Dodatkowo istniałoby niebezpieczeństwo, iż kandydaci skupiliby się na prowadzeniu kampanii jedynie w mediach, nie mając tym samym szans na zapoznanie się z potrzebami danych stanów bądź regionów.

Zaprezentowane projekty pokazują, że istnieje potencjał zarówno wśród organizacji, niezależnych reformatorów, jak i pojedynczych polityków do przeprowadzenia reform systemu wyborczego na bardziej reprezentatywny i odpowiadający proporcjonalnemu rozkładowi elektoratu. Jednakże narodowej zgody, zwłaszcza wśród partii politycznych, które zdominowały scenę polityczną, nadal nie ma, co powoduje, że z każdymi wyborami rosną dysproporcje w reprezentacji pomiędzy wyborcami a przedstawicielami.

63 L.J. Sabato, A Missing Constitutional Link? Politics and Its Place in Our Governing Document, 18.10.2007, http://www.centerforpolitics.org/crystalball/articles/ljs2007101801/, odczyt z dn. 29.11.2012. 